\title{
Pengaruh Kualitas Sumber Daya Manusia dan Profesionalisme Kerja Terhadap Kinerja Karyawan Pada PT. PIN (Persero) Pelaksana Pembangkit Bukit Asam Tanjung Enim
}

\author{
Kina Atika', Nisa' Ulul Mafra ${ }^{2}$ \\ ${ }^{1}$ Manajemen, Fakultas Ekonomi dan Bisnis Universitas PGRI Palembang, kina@gmail.com \\ ${ }^{2}$ Manajemen, Fakultas Ekonomi dan Bisnis Universitas PGRI Palembang, nisaulul29@gmail.com
}

\begin{abstract}
ABSTRAK
Penelitian ini bertujuan untuk mengetahui pengaruh kualitas sumber daya manusia dan profesionalisme kerja terhadap kinerja karyawan pada PT.PLN (Persero) Pelaksana Pembangkit Bukit Asam Tanjung Enim. Metode kuantitatif asosiatif digunakan dalam penelitian ini dengan sampel sebanyak 59 orang dari populasi 142 orang karyawan yang ada pada PT. PLN (Persero) dengan menggunakan rumus Slovin. Uji instrumen dan uji klasik menunjukkan semua data valid dan reliabel dan memenuhi kriteria pengujian sehingga penelitian dapat dilanjutkan dengan meregresi linear berganda data tersebut. Hasil uji t membuktikan bahwa secara parsial kualitas SDM (8,535 atau $0,000)$ dan profesionalisme kerja $(11,545$ atau 0,000$)$ berpengaruh terhadap Kinerja Karyawan. Uji $F$ juga menunjukkan hasil yang sama secara simultan dengan hasil uji sebesar 852,303 atau 0,000. Koefisien korelasi $(R)$ diperoleh hasil sebesar 0,984 atau sebesar $98,4 \%$ artinya hubungan variabel kualitas sumber daya manusia dan profesionalisme kerja sangat kuat terhadap kinerja karyawan pada PT. PLN (Persero) Pelaksana Pembangkit Bukit Asam Tanjung Enim. Nilai R Square sebesar 0,968 atau sebesar $96,8 \%$ artinya kinerja karyawan dipengaruhi oleh kualitas sumber daya manusia dan profesionalisme kerja, sedangkan sisanya sebesar 3,2 \% kinerja karyawan dipengaruhi oleh variabel variabel lainnya yang tidak diteliti dalam penelitian ini.
\end{abstract}

Kata kunci : Kualitas Sumber Daya Manusia, Profesionalisme Kerja, Kinerja Karyawan

\section{ABSTRACT}

This study aims to determine the effect of human resource quality and work professionalism on employee performance at PT PLN (Persero) Implementing the Bukit Asam Tanjung Enim Power Plant. Associative quantitative method used in this study with a sample of 59 people from a population of 142 employees who are at PT. PLN (Persero) using the Slovin formula. Instrument test and classical test show that all data are valid and reliable and meet the testing criteria so that research can be continued with multiple linear regression of the data. The results of the t test prove that partially the quality of human resources $(8,535$ or 0,000$)$ and work professionalism $(11,545$ or 0,000$)$ have an effect on employee performance. The $\mathrm{F}$ test also shows the same results simultaneously with the test results of 852,303 or 0,000 . The correlation coefficient $(R)$ is 0.984 or $98.4 \%$, meaning that the relationship between the quality of human resources and work professionalism is very strong on the performance of employees at PT. PLN (Persero) Implementing the Bukit Asam Tanjung Enim Power Plant. The R Square value of 0.968 or $96.8 \%$ means that employee performance is influenced by the quality of human resources and work professionalism, while the remaining $3.2 \%$ of employee performance is influenced by other variables not examined in this study. This study aims to determine the effect of human resource quality and work professionalism on employee performance at PT PLN (Persero Implementing the Bukit Asam Tanjung Enim Power Plant.

Keywords: Quality of Human Resources, Work Professionalism, Employee Performance

\section{A. PENDAHULUAN}

Tujuan PT. PLN (Persero) yang merupakan BUMN di bidang jasa pelayanan listrik untuk menyediakan serta melayani kebutuhan dan kepentingan pelanggan akan tenaga

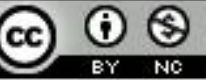

is licensed under a Creative Commons Attribution-NonCommercial 4.0 International License. 
listrik. PT. PLN (persero) memegang peranan penting bagi kehidupan masyarakat. Dengan banyaknya pemasokan listrik secara tidak langsung perusahaan ini mengalami penumpukan dalam ruang lingkup pekerjaannya yang meliputi, (a) usaha penyediaan tenaga listrik, diantaranya pembangkitan, penyaluran, distribusi, perencanaan, pembangunan sarana penyediaan tenaga listrik dan pengembangan penyediaan tenaga listrik. (b) usaha penunjang tenaga listrik, diantarannya konsultasi yang berhubungan ketenagalistrikan, pembangunan dan pemasangan peralatan ketenagalistrikan, pemeliharaan peralatan keteganggan listrik dan pengembangan teknologi peralatan yang menunjang penyediaan tenaga listrik. (c) usaha lain, diantaranya kegiatan usaha dan pemanfaatan sumber daya alam dan sumber energi terkait penyediaan ketenaga listrikan, jasa operasi dan pengaturan bidang pembangkit, penyaluran, distribusi dan retail tenaga listrik, kegiatan perindustrian perangkat keras dan luas bidang ketenagalistrikan, kerja sama dengan bidang lain dan usaha lainnya.

Melihat padatnya pekerjaan yang harus dilakukan, pasti membutuhkan karyawan yang berkualitas dan mampu bekerja secara profesional. Sumber daya manusia dapat dikatakan berkualitas manakala mereka mempunyai kemampuan untuk melaksanakan kewenangan dan tanggung jawab yang diberikan kepadanya dengan berbekal pendidikan, latihan dan pengalaman yang cukup memadai (Widodo,2015:8). Kemudian keandalan dan keahlian dalam pelaksanaan tugas sehingga terlaksana dengan mutu tinggi, waktu yang tepat, cermat dan dengan prodesur yang mudah dipahami disebut profesionalisme
(Siagian,2010:169). Setiap pekerjaan memiliki standar sendiri. Hal ini dapat diukur dengan kinerja sebagai prestasi kerja yakni perbandingan antara hasil kerja yang secara nyata dengan standar kerja yang ditetapkan (Dessler, 2015:12).

Tetapi pada kenyataan dari begitu banyak pekerjaan, PT. PLN masih minim akan sumber daya manusia yang berkualitas, sarana dan prasarana kurang memadai, begitu juga dengan minimnya para teknis di lapangan yang berkompetensi dalam bidangnya. Untuk memenuhi banyaknya permintaan dan pelayanan kepada masyarakat/pelanggan, PT. PLN menjalin kerja sama dengan badan hukum lain, seperti pemborongpemborong, perusahaan-perusahaan, penagih seperti koperasi, atau bank dengan tujuan agar kualitas pelayanan teratasi dengan cepat dan memberikan kepuasaan kepada masyarakat.

Jika dilihat dari fenomena yang ada, masih kurangnya profesionalisme dan kualitas sumber daya manusia yang tinggi pada PT. PLN menyebabkan pekerjaan yang dilakukan oleh para karyawan tidak sesuai dengan prosedur, seperti kurangnya pengawasan terhadap vendor membuat karyawan meninggalkan tanggung jawabnya sehingga sisa pekerjaan yang dilakukannya itu belum sepenuhnya dirapikan.

Tujuan yang ingin dicapai dalam penelitian ini untuk mengetahui pengaruh kualitas sumber daya manusia dan profesionalisme kerja secara parsial dan simultan terhadap kinerja karyawan pada PT. PLN (Persero) Pelaksana Pembangkit Bukit Asam. Penelitian serupa pernah dilakukan dengan variabel yang sama antara lain: Thamrin. Agung S,dkk( 2017), Kasannudin (2011). Gerhana 
dkk (2019), Aisyah dkk ( 2015) dan Ardi (2017).

\section{B. KAJIAN TEORI}

\section{Kualitas Sumber Daya Manusia}

Kemampuan seorang karyawan yang menjalankan tugas dan tanggung jawab yang diberikan padanya dengan memiliki latar belakang pendidikan, keterampilan dan pengalaman untuk menunjang tugas dan tanggung jawab yang akan dijalankan agar perusahaan mampu bersaing dimaknai (Sunarto dalam Aisyah, 2012:70)

\section{Pengukuran Kualitas Sumber Daya Manusia}

Kualitas sumber daya manusia menurut Kasanuddin dalam Aisyah dkk, (2015:7) dapat diukur dengan menggunakan teori:

a. Produktivitas, untuk mencapai produktivitas kerja yang maksimum, organisasi harus menjamin dipilinnya orang yang tepat dengan pekerjaan yang tepat serta kondisi yang memungkinkan mereka bekerja.

b. Sikap dan Perilaku

\section{Sikap}

Sikap yang perlu dipupuk dan dikembangkan dalam merencanakan masa depan yang diinginkan.

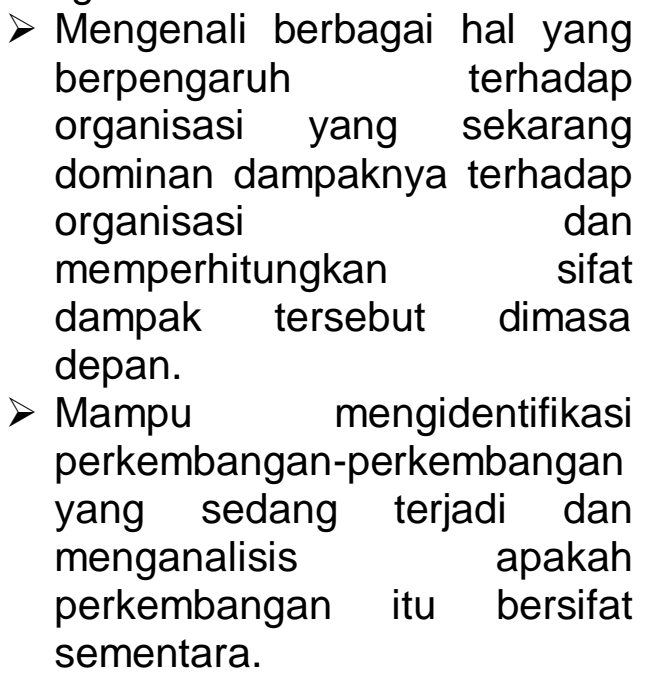

Mampu

melihat kecenderungankecenderungan yang timbul dan mengaitkan itu dengan sasaran-sasaran yang diinginkan.

Tidak sekedar memberikan reaksi terhdap situasi problematik yang timbul, akan tetapi memperhitungkan sebelumnya.

Mampu berpikir dan bertindak proaktif.

2. Perilaku, yang dasarnya berorientasi pada tujuan (goaloriented). Dengan kata lain, perilaku kita pada umumnya dimotivasi oleh keinginan untuk mencapai tujuan tertentu.

c. Komunikasi, sebagai penyampaian informasi antara dua orang atau lebih yang juga meliputi pertukaran informasi antara manusia dan mesin baik komunikasi dari sisi komunikasi antara pribadi dan komunikasi organisasi. komunikasi dapat terjadi karena adanya komponenkomponen, yaitu komunikator yang mengirimkan pesan yang diekspresikan (enconed) melalui berbagai lambang dalam bentuk bahasa. Selanjutnya pesan disampaikan melalui perantara yaitu media komunikasi.

Teknik berkomunikasi secara efektif (Siagian dalam Aisyah dkk,2015:8), antara lain adalah :

1) Setiap orang dalam organisasi harus mengetahui semua saluran komunikasi yang terdapat dalam organisasi.

2) Mengetahui saluran komunikasi yang terbuka baginya dan bagaimana tata cara penggunaannya.

3) Garis komunikasi secara langung dan sesingkat mungkin guna menghindari distrosi dalam proses komunikasi. 
4) Harus terdapat kemungkinan untuk menggunakan semua jalur formal dengan mengindahkan hirarki organisasi yang berlaku.

5) Garis komunikasi hendaknya diusahakan agar tidak terganggu meskipun berbagai kegiatan berlangsung dalam organisasi yang bersangkutan.

6) Otensitas komunkasi hendaknya terjamin.

7) Orang yang bertidak sebagai pusat komunikasi hendaknya terdiri dari orang yang terampil.

d. Hubungan (Relationships), artinya membuka peluang dan sekaligus mengikat simpul-simpul informasi dan menggerakkan kehidupan. Manusia yang tidak atau enggan bersilaturahmi untuk membuka cakrawala pergaulan sosialnya atau menutup diri dan asyik dengan dirinya sendiri, pada dasarnya ia sedang mengubur masa depannya.

\section{Indikator-Indikator Kualitas Sumber Daya Manusia}

Kasanuddin

mengatakan bahwa indikator dari kualitas sumber daya manusia adalah sebagai berikut: a) Kualitas intelektual meliputi pengetahuan dan keterampilan), b) Pendidikan, c) Memahami bidangnya, d) Kemampuan, e) Semangat kerja dan f) Kemampuan perencanaan pengorganisasian.

\section{Profesionalisme Kerja}

Kemampuan dan keahlian dalam pelaksanaan tugas sehingga terlaksana dengan mutu tinggu, waktu yang tepat, cermat dan dengan prosedur yang mudah dipahami dan diikuti oleh pelanggan (Pratiwi dalam Aisyah dkk,2015:9) .

\section{Ciri - Ciri Profesionalisme Kerja}

Orang yang memiliki
profesionalisme dalam bekerja
menurut Aisyah dkk $(2015: 10)$
ciri: a) Profiri-
sifat mengionalisme menghendaki
sehingga kita di tuntut untuk selalu
mencari Profesionalisme memerlukan kesungguhan dan ketelitian kerja yang harus dapat diperoleh melalui pengalaman dan kebiasaan; c) Profesionalisme menuntut ketekunan dan ketabahan yaitu sikap tidak mudah puas dan putus asa sampai hasil tercapai; d) Profesionalisme memerlukan integritas tinggi yang tidak tergoyahkan oleh keadaan terpaksa atau godaan iman seperti harta, kenikmatan hidup; e) Profesionalisme memerlukan adanya kebulatan pikiran dan perbuatan sehingga terjaga efektivitas kerja yang tinggi. Berdasarkan dari uraian ciri-ciri tersebut, profesionalisme karyawan dapat diukur melalui: efektif dan efisien, teliti, ulet, berintegritas dan konsekuen.

\section{Karakteristik Profesionalisme}

Menurut Thamrin dkk (2017:5) karakteristik profesionlisme aparatur sesuai dengan tuntunan good governance, diantaranya: a) Equality (kesaman atau kesetaraan), perlakuan yang sama atas pelayanan yang diberikan; b) Equity (keadilan), selain perlakuan yang sama kepada masyarakat, juga adanya perlakuan yang adil dan sama.c) Loyality (Loyalitas), kesetiaan diberikan kepada konstitusi hukum, pimpinan, bawahan dan rekan kerja; d) Accountability (akutanbilitas), setiap aparat pemerintah harus siap menerima tanggung jawab atas apapun yang ia kerjakan. Setiap pegawai harus memegang teguh kode etik dan prinsip-prinsip yang ditetapkan institusi. 


\section{Indikator Profesionalisme Kerja}

Sedarmayanti

(2010:15)

mengatakan bahwa indikator dari profesionalisme kerja adalah sebagai berikut: kompetensi, efektifitas, efisiensi dan tanggung jawab.

\section{Kinerja Karyawan}

Hasil kerja yang dapat dicapai karyawan baik individu maupun kelompok dalam suatu organisasi, sesuai dengan wewenang dan tanggung jawab yang diberikan organisasi dalam upaya mencapai visi, misi dan tujuan organisasi bersangkutan dengan menyertakan kemampuan, ketekunan, kemandirian, kemampuan mengatasi masalah sesuai batas waktu yang diberikan secara legal dan sesuai dengan moral maupun etika (Busro, 2018:89).

Faktor Yang Mempengaruhi Kinerja Pegawai

Faktor yang mempengaruhi pencapaian kinerja menurut Mangkunegara (2017:67) antara lain, yaitu :

a) Faktor kemampuan, secara psikologis, kemampuan (ability) pegawai terdiri dari kemampuan potensi (IQ) dan kemampuan reality (knowledge + skill). Artinya, karyawan yang memiliki $I Q$ diatas rata-rata (IQ 110-120) dengan pendidikan yang memadai untuk jabatannya dan terampil dalam menegrjakan pekerjaan sehari-hari, maka ia akan lebih mudah mencapai kinerja yang diharapkan. Oleh krena itu, pegawai perlu ditempatkan pada pekerjaan yang sesuai dengan keahliannya.

b) Faktor motivasi, terbentuk dari sikap (attitude) seorang karyawan dalam menghadapi situasi (situation) kerja. Artinya, seorang pegawai harus siap mental, mampu secara fisik, memahami tujuan utama dan target kerja yang harus akan dicapai, mampu memanfaatkan, dan menciptakan situasi kerja. Motivasi merupakan kondisi yang menggerakkan diri karyawan yang terarah untuk mencapai tujuan organisasi (tujuan kerja).

\section{Indikator Kinerja}

Wibowo (2017:88) mengatakan bahwa indikator dari kinerja karyawan adalah sebagai berikut :

a) Tujuan, merupakan kedaaan yang berada yang secara aktif dicari oleh seseorang individual atau organisasi untuk capai.

b) Standar, mempunyai arti penting karena memberitahukan kapan suatu tujuan dapat diselesaikan. Standar merupakan suatu ukuran apakah tujuan yang diinginkan dapat dicapai.

c) Umpan balik, melaporkan kemajuan, baik kualitas maupun kuantitas, dalam mencapai tujuan didefinisikan oleh standar, umpan balik terutama penting ketika kita mempertimbangkan "real goals" atau tujuan sebenarnya. Tujuan yang dapat diterima oleh pekerja adalah tujuan yang bermakna dan berharga.

d) Alat dan saran, merupakan sumber daya manusia dapat dipergunakan untuk membantu menyelesaikan tujuan dengan akses. Alat sarana merupakan faktor penunjang untuk mecapai tujuan. Tanp alat dan sarana, tugas pekerjaan spesifik tidak dapat dilakukan dan tujuan tidak dapat diselesaikan sebagaimana harusnya.

e) Kompetensi, merupakan perysaratan utama dalam kinerja. Kompetensi merupakan kemampuan yang dimiliki oleh seseorang untuk menjalankan pekerjaan yang diberikan kepadanya dengan baik. 
f) Motif, alasan atau pendorong bagi seseorang untuk melakukan sesuatu.

g) Peluang, Pekerja perlu mendapatkan kesempatan untuk menunjukkan prestasi kerjanya. Terdapat dua faktor yang menyambungkan adanya kekurangan kesempatan berprestasi, yaitu ketersediaan waktu dan kemampuan untuk memenuhi syarat.

\section{Hipotesis Penelitian}

Hipotesis sebagai jawaban sementara terhadap rumusan masalah penelitian menduga ada pengaruh signifikan kualitas sumber daya manusia dan profesionalisme kerja secara parsial dan simultan terhadap kinerja karyawan pada PT. PLN (Persero) Pelaksana pembangkit Bukit Asam Tanjung Enim.

\section{METODE PENELTIAN}

Penelitian ini dilakukan di PT. PLN (Persero) Pelaksana Pembangkit Bukit Asam Tanjung Enim. Beralamatkan di Jl. Lingga Raya, Tanjung Enim, Sumatera Selatan Telp. (0734) 451052, 451053 Fax. (0734) $451051 \quad$ Web.www.pln-kitsbs.co.id Sumatera Selatan 31701.

Metode Kuantitatif asosiatif digunakan dalam penelitian ini untuk melihat pengaruh variabel bebas terhadap variabel terikat. Metode kuantitatif dapat diartikan sebagai metode penelitian yang berlandaskan pada filsafat positivisme, digunakan untuk meneliti pada populasi atau sampel tertentu, pengumpulan data menggunakan instrumen penelitian, analisis data bersifat kuantitatif/statistik, dengan tujuan untuk menguji hipotesis yang telah ditetapkan (Sugiyono, 2018:35).

Variabel penelitian yang merupakan suatu atribut atau sifat atau nilai dari orang, obyek, organisasi atau kegiatan yang mempunyai variasi tertentu yang ditetapkan oleh peneliti untuk dipelajari dan kemudian ditarik kesimpulannya (Sugiyono,2018:96). Terdapat 2 Variabel dalam penelitian ini, yaitu: variabel independen yaitu Kualitas Sumber Daya Manusia $\left(X_{1}\right)$ dan Profesionalisme Kerja $\left(\mathrm{X}_{2}\right)$. Selajutnya variabel dependen yaitu Kinerja Karyawan $(\mathrm{Y})$.

Populasi sebanyak 142 orang karyawan yang bekerja di PT. PLN (persero) Pembangkit Bukit Asam Tanjung Enim, tetapi Jumlah responden yang digunakan sebagai sampel penelitian adalah 59 orang menggunakan rumus Slovin.

Sumber data yang disesuaikan untuk pengambilan data dalam penelitian ada 2 (Sujarweni, 2015:89) yaitu : 1) Data primer, merupakan data yang diperoleh dari responden melalui kuisioner, kelompok fokus dan panel atau juga data hasil wawancara penelitian dengan narasumber. 2) Data Sekunder, merupakan data yang didapat dari catatan, buku dan majalah berupa laporan perusahan, laporan pemerintah, buku-buku sebagai teori, majalah berupa dan sebagainya.

Adapun jenis teknik pengumpulan data yang dilakukan dalam penelitian ini adalah: a) Kuesioner (Angket), merupakan teknik pengumpulan data yang dilakukan dengan cara memberi seperangkat pertanyaan atau pernyataan tertulis kepada responden untuk dijawabnya. b) Dokumentasi, yang terdiri dari catatan peristiwa yang sudah berlalu. Dokumen dapat berbentuk tulisan gambar atau karyakarya monumental dari seseorang.

Sebelum sampai pada tahap selanjutnya, data perlu diuji dengan melakukan uji validitas untuk mengetahui ketepatan alat ukur (kuesioner) dan reliabilitas untuk 
mengetahui konsistensi alat ukur tersebut.

Jenis uji asumsi klasik yang dilakukan antara lain: a) Uji Normalitas untuk melihat model regresi variabel berdistribusi normal atau tidak. b) Uji Multikolinieritas, untuk menguji adanya korelasi antara variabel bebas. c) Uji Heteroskedastisitas, varian residual yang tidak sama pada semua pengamatan didalam model regresi. Uji ini bertujuan untuk menguji apakah dalam model regresi terjadi ketidaksamaan varian dari residual satu pengamatan ke pengamatan lain. Model regresi yang baik adalah yang homoskedastisitas atau tidak terjadi heteroskedastisitas.

Kemudian teknik analisis data Regresi Linier Berganda untuk mengetahui pengaruh kualitas sumber daya manusia dan profesionalisme kerja terhadap kinerja karyawan pada PT. PLN (persero) pelaksana Pembangkit Bukit Asam Tanjung Enim maka digunakan rumus regresi linier dengan dua prediktor:

Dimana:

$$
\begin{array}{|c|}
\mathrm{Y}=\mathrm{a}+\mathrm{b}_{1} \mathrm{X}_{1}+\mathrm{b}_{2} \mathrm{X}_{2}+\mathrm{e} \\
\mathrm{Y} \quad \text { = Variabel terikat }
\end{array}
$$

$$
\begin{array}{ll}
\mathrm{X}_{1} & =\text { Variabel bebas pertama } \\
\mathrm{X}_{2} & =\text { Variabel bebas kedua }
\end{array}
$$

a dan $\mathrm{b}=$ konstanta

e $=$ error term

Koefisien Determinasi $\left(\mathrm{R}^{2}\right)$, untuk melihat pengaruh variabel bebas terhadap variabel bebas, sedangkan koefisien korelasi (R) untuk melihat kuat tidaknya hubungan kedua variabel tersebut.

Untuk menjawab hipotesis perlu beberapa uji, antara lain uji parsial (Uji t). Untuk melihat pengaruh kualitas sumber daya manusia dan profesionalisme kerja secara parsial terhadap kinerja karyawan pada PT. PLN (Persero) Pelaksana Pembangkit Bukit Asam Tanjung Enim. Uji simultan (Uji F) untuk melihat pengaruh kualitas sumber daya manusia dan profesionalisme kerja secara simultan terhadap kinerja karyawan pada PT. PLN (Persero) Pelaksana Pembangkit Bukit Asam Tanjung Enim.

\section{HASIL PENELITIAN} Karakterisik Responden

Data responden dirangkum untuk mendukung hasil penelitian disajikan dalam bentuk tabel.

Tabel Karakteristik Responden

\begin{tabular}{|c|c|c|}
\hline Karakteristik & Frekuensi & Persentase \\
\hline Jenis Kelamin & \multicolumn{3}{|c|}{} \\
\hline Laki - laki & 40 & $58,82 \%$ \\
Perempuan & 19 & $41,18 \%$ \\
\hline Jumlah & $\mathbf{5 9}$ & $\mathbf{1 0 0} \%$ \\
\hline \multicolumn{3}{|c|}{ Tingkat Usia } \\
\hline $20-30$ & 35 & $59 \%$ \\
$31-40$ & 16 & $27 \%$ \\
> 41 & 7 & $14 \%$ \\
\hline Jumlah & $\mathbf{5 9}$ & $\mathbf{1 0 0} \%$ \\
\hline \multicolumn{3}{|c|}{ Pendidikan } \\
SMK/SMA & 10 & $16,95 \%$ \\
D3 & 15 & $25,42 \%$ \\
S1 & 25 & $42,37 \%$ \\
>S1 & 9 & $15,26 \%$ \\
\hline Jumlah & $\mathbf{5 9}$ \\
\hline \multicolumn{2}{|c|}{} \\
\hline
\end{tabular}




\begin{tabular}{|c|c|c|}
\hline $\begin{array}{c}1-10 \\
11-20 \\
>21\end{array}$ & $\begin{array}{l}30 \\
19 \\
10\end{array}$ & $\begin{array}{l}50,85 \% \\
32,20 \% \\
16,95 \%\end{array}$ \\
\hline Jumlah & 59 & $100 \%$ \\
\hline
\end{tabular}

Sumber: Data Diolah, 2019

Semua data responden pada tabel di atas menggambarkan bahwa karyawan lebih didominasi oleh lakilaki (58,82\%).Usai karyawan lebih muda antara 20-30 tahun. Pendidikan lebih banyak berstrata 1 (42,37\%) dan masa kerja lebih lebih banyak antara $1-10$ tahun $(50,85 \%)$.

\section{Hasil Pengujian Instrumen}

Semua data yang diperoleh dari kuesioner telah memenuhi kriteria uji. Uji validasi dengan nilai antara 0,377 s.d 0,883 variabel kualitas sumber daya manusia $\left(X_{1}\right)$. 0,357 s.d 0,888 variabel profesionalisme kerja $\left(\mathrm{X}_{2}\right)$ dan 0,366 s.d 0,762 variabel kinerja karyawan $(Y)$ dengan nilai $\alpha=5 \%$ $(0,256)$ dinyatakan valid. Nilai reliabilitas berkisar antara 0,187 s.d
0,916 lebih besar dari 0,60 sehingga semua data dianggap reliabel.

\section{Pengujian Asumsi Klasik}

Uji one sample KolmogorovSmirnov menunjukkan data berdistribusi normal dengan nilai $0,0,73$ s.d 0,170 lebih besar dari $\alpha=$ $5 \%(0,05)$. Nilai tolerance 0,233 >0,1 dan Variance Inflation factor 4,487< 10 menyatakan tidak terjadi multikolinieritas. Selanjutnya uji heteroskedastisitas menunjukkan tidak terjadi heterokedastisitas karena nilai variabel $1,00>0,05$.

\section{Analisis Data}

Hasil regresi linear berganda dan koefisien korelasi dan determinasi ditunjukkan pada tabel berikut.

Tabel Regresi Linear Berganda dan Koefisien

\begin{tabular}{|c|c|c|c|}
\hline \multicolumn{2}{|c|}{ Variabel } & \multirow{2}{*}{\multicolumn{2}{|c|}{$\begin{array}{c}\text { Koefisien Regresi } \\
1,750\end{array}$}} \\
\hline \multirow{3}{*}{$\begin{array}{l}\text { Kinerja } \\
\text { Karyawan }\end{array}$} & & & \\
\hline & Kualitas SDM & \multicolumn{2}{|c|}{.456} \\
\hline & Profesional Kerja & \multicolumn{2}{|c|}{,681 } \\
\hline \multirow[t]{3}{*}{ Koefisien } & & $\mathbf{R}$ & R Square \\
\hline & Korelasi &, $984^{a}$ & \\
\hline & Determinasi & & ,968 \\
\hline
\end{tabular}

Sumber: Data diolah,2019

Nilai pada tabel menunjukkan bahwa: $Y=1,750+0,456 X_{1}+0,681$ $\mathrm{X}_{2}$, berarti nilai konstanta sebesar 1,750 , hal ini berarti jika variabel kualitas sumber daya manusia $\left(X_{1}\right)$ dan variabel profesionalisme kerja $\left(X_{2}\right)$ sama dengan nol, maka kinerja karyawan $(Y)=1,750$. Apabila variabel kualitas sumber daya manusia $\left(X_{1}\right)$ bernilai 0,456 satu satuan sedangkan variabel yang lainnya tetap, maka akan diikuti dengan peningkatan kinerja karyawan sebesar 0,456 satu satuan. Kenyataan akan berbalik jika terjadi sebaliknya. Nilai 0,681 pada variabel profesionalisme kerja $\left(\mathrm{X}_{2}\right)$ menunjukkan peningkatan sebesar 0,681 satu satuan jika variabel lainnya tetap yang diikuti dengan peningkatan kinerja karyawan sebesar 0,681 satu satuan. Jika nilai menunjukkan kebalikannya maka keadaan pun akan berbalik.

Koefisien korelasi (R) dapat 
dikatakan sangat kuat dengan diperoleh hasil sebesar 0,984 atau sebesar 98,4\% terhadap kinerja karyawan pada PT. PLN (Persero) Pelaksana Pembangkit Bukit Asam Tanjung Enim. Nilai R Square sebesar 0,968 atau sebesar $96,8 \%$ artinya kinerja karyawan dipengaruhi oleh kualitas sumber daya manusia dan profesionalisme kerja, sedangkan sisanya sebesar $3,2 \%$ kinerja karyawan dipengaruhi oleh variabelvariabel lainnya yang tidak diteliti dalam penelitian ini, seperti komunikasi, lingkungan kerja dan lainlain.

\section{Pengujian Hipotesis}

Hasil output pengujian secara parsial diperoleh nilai yang ditunjukkan pada tabel berikut:

Tabel Hasil Uji t

\begin{tabular}{|l|r|r|c|c|}
\hline Variabel & Uji t & Sig. & $\mathbf{t}_{\text {tabel }}$ & Sig $\mathbf{\alpha = 5 \%}$ \\
\hline (Constant) & 1,288 &, 203 & & \\
Kualitas SDM & 8,535 &, 000 & \multirow{2}{*}{2,003} & \multirow{2}{*}{0,05} \\
Profesionalisme Kerja & 11,545 &, 000 & & \\
\hline
\end{tabular}

\section{Sumber : Data diolah, 2019}

Uji $t$ variabel kualitas SDM menunjukkan nilai 0,000 , yang artinya lebih kecil Nilai $\alpha=0,05$. Sehingga dapat disimpulkan bahwa secara parsial Kualitas SDM ada pengaruh yang signifikan terhadap Kinerja Karyawan.

Hasil uji t variabel profesionalisme kerja diperoleh nilai 0,000 .yang artinya lebih kecil Nilai $\alpha=0,05$. Sehingga dapat disimpulkan bahwa secara parsial profesionalisme kerja ada pengaruh yang signifikan terhadap Kinerja Karyawan

\section{Uji F (Secara simultan)}

Pada dasarnya uji statistik $F$ menunjukkan apakah semua variabel independen (bebas) mempunyai pengaruh secara bersama-sama (simultan) terhadap variabel independen (terikat).

Hasil perhitungan uji $\mathrm{F}$ dapat dilihat pada tabel berikut:

Tabel Hasil Uji F (ANOVA ${ }^{a}$ )

\begin{tabular}{|l|c|c|c|c|}
\hline Model & Uji F & Sig. & $F_{\text {tabel }}$ & Sig $\alpha=5 \%$ \\
\hline $\begin{array}{l}\text { Regression } \\
\text { Residual }\end{array}$ & 852,303 &, $000^{\mathrm{b}}$ & & \\
Total & &, 000 & 3,160 & 0,05 \\
\hline
\end{tabular}

Sumber : Data Diolah, 2019

Hasil uji F untuk kedua variabel independen diperoleh nilai signifikansi $=0,000$, ini berarti signifikansi $0,000<$ 0,05, maka Ho ditolak dan Ha diterima.

Hasil uji tersebut dapat diketahui bahwa secara simultan variabel kualitas sumber daya manusia dan profesionalisme kerja ada pengaruh yang signifikan terhadap variabel kinerja karyawan. Sehingga hipotesis yang menyatakan variabel kualitas sumber daya manusia dan profesionalisme kerja secara simultan ada pengaruh yang signifikan terhadap kinerja karyawan telah terbukti. 
E. PEMBAHASAN

1) Pengaruh Kualitas SDM terhadap Kinerja Karyawan pada PT. PLN (Persero) Pelaksana Pembangkit Bukit Asam Tanjung Enim

Pengujian uji $\mathrm{t}$ variabel kualitas SDM diperoleh nilai signifikan 0,000< 0,05, dengan demikian dapat disimpulkan bahwa secara parsial kualitas SDM $\left(X_{1}\right)$ terdapat pengaruh yang signifikan terhadap produktivitas $\operatorname{kerja}(Y)$.

Kualitas sumber daya manusia dianggap sangat penting dalam peranannya dalam pencapaian kinerja karyawan yang bertujuan mengatur pengelolaan kualitas sumber daya manusia agar memberikan hasil yang maksimal, memiliki loyalitas tinggi, dan mampu menjalankan tugas sebagai mestinya.

Penelitian ini sama dengan penelitian terdahulu yang dilakukan oleh Aisyah dkk (2015) dalam judulnya adalah pengaruh kualitas sumber daya manusia, profesionalisme kerja dan komitmen terhadap kinerja karyawan PDAM Kabupaten Jember. Dalam hal ini bahwa kualitas sumber daya manusia berpengaruh signifikan terhadap kinerja karyawan.

\section{2) Pengaruh Profesionalisme Kerja terhadap Kinerja Karyawan pada PT. PLN (Persero) Pelaksana Pembangkit Bukit Asam Tanjung Enim}

Hasil uji t (secara parsial) variabel profesionalisme kerja diperoleh nilai signifikan $0,000<\alpha$ 0,05. Dengan demikian dapat disimpulkan bahwa secara parsial profesionalisme kerja $\left(\mathrm{X}_{2}\right)$ terdapat pengaruh yang signifikan terhadap produktivitas kerja $(Y)$.

Sangat penting bagi setiap karyawan memiliki profesionalisme dalam bekerja untuk pencapaian kinerja, karena didalam profesionalisme tersebut terkandung keahlian dalam mengoptimalkan ilmu pengetahuan, skill, waktu, tenaga, sumber daya, serta sebuah strategi pencapaian dalam suatu pekerjaan.

Penelitian ini sama dengan penelitian terdahulu yang dilakukan oleh Ardi (2017) dalam judulnya adalah pengaruh kualitas profesionalisme kerja dan komitmen organisasi terhadap kinerja karyawan pada kantor Inspektorat Provinsi Sulawesi Selatan. Dalam hal ini bahwa profesionalisme kerja dan komitmen organisasi berpengaruh signifikan terhadap kinerja karyawan.

3) Pengaruh Kualitas SDM dan Profesionalisme Kerja terhadap Kinerja Karyawan pada PT. PLN (Persero) Pelaksana Pembangkit Bukit Asam Tanjung Enim

Hasil uji F (secara silmutan) variabel kualitas SDM $\left(\mathrm{X}_{1}\right)$ dan profesionalisme kerja $\left(X_{2}\right)$ memperoleh nilai $F_{\text {hitungsebesar } 852,303}$ dan diperoleh nilai $F_{\text {tabel }}$ sebesar 3,16 dan taraf signifikan $0,000<0,05$. Hasil ini membuktikan Kualitas SDM dan profesionalisme kerja ada berpengaruh signifikan terhadap Kinerja Karyawan (Y). Artinya semakin baik kualitas SDM Karyawan akan semakin baik kinerja yang bisa dicapai dan semakin profesional setiap karyawan akan meningkatkan kinerja. Dengan begitu kedua varibel ini memang sangat dibutuhkan dalam pencapaian kinerja karyawan.

Hasil ini sama dengan penelitian yang dilakukan Gerhana dkk (2019) yang memberikan kesimpulan kualitas SDM dan profesionalisme berpengaruh positif dan signifikan terhdap kinerja karyawan Dinas pendidikan Hulu Sungai Selatan. 
Koefisien korelasi ( $R$ ) diperoleh hasil sebesar 0,984 atau sebesar $98,4 \%$ artinya hubungan variabel kualitas sumber daya manusia dan profesionalisme kerja sangat kuat terhadap kinerja karyawan pada PT. PLN (Persero) Pelaksana Pembangkit Bukit Asam Tanjung Enim.

Hasil R Square (Koefisien determinasi) sebesar 0,968 atau sebesar $96,8 \%$ artinya kinerja karyawan dipengaruhi oleh kualitas sumber daya manusia dan profesionalisme kerja, sedangkan sisanya sebesar 3,2 \% kinerja karyawan dipengaruhi oleh variabel variabel lainnya yang tidak diteliti dalam penelitian ini.

\section{F. KESIMPULAN}

Berdasarkan hasil dan analisis data yang dilakukan dapat ditarik beberapa kesimpulan dari penelitian ini yakni sebagai berikut:

a. Secara parsial kualitas SDM ada pengaruh yang signifikan terhadap kinerja karyawan. Hal ini berarti bahwa kualitas SDM yang baik pada PT. PLN (Persero) Pelaksana Pembangkit Bukit Asam Tanjung Enim akan meningkatkan kinerja karyawan

b. Secara parsial profesionalisme kerja memiliki pengaruh yang signifikan terhadap konerja karyawan. Hal ini berarti bahwa apabila karyawan memiliki profesionalisme kerja yang tinggi padaPT. PLN (Persero) Pelaksana Pembangkit Bukit Asam Tanjung Enim maka kinerja karyawan akan meningkat.

c. Secara simultan kualitas SDM dan profesionalisme kerja memiliki pengaruh yang signifikan terhadap konerja karyawan pada PT. PLN (Persero) Pelaksana Pembangkit Bukit Asam Tanjung Enim. Dapat disimpulkan bahwa apabila kedua variabel ini dapat ditingkatkan secara bersamasama maka kinerja karyawan juga akan meningkat.

\section{G. SARAN}

Saran yang diharapkan dapat menjadi masukan atau bahan pertimbangan bagi perusahaan yakni sebagai berikut:

a. Kualitas Sumber Daya Manusia pada PT. PLN (Persero) Pelaksana Pembangkit Bukit Asam Tanjung Enim sudah cukup baik, akan tetapi perlu di tingkatkan lagi agar kinerja karyawan juga akan meningkat dengan memperbanyak pelatihan atau workshop, memberikan lingkungan kerja yang baik dan bentuk team manajemen yang baik akan timbul kinerja karyawan yang baik pula, jadi semakin tinggi kualitas sumber daya manusia yang baik akan menciptakan kinerja karyawan yang baik pula.

b. Profesionalisme kerja karyawan PT. PLN (Persero) Pelaksana Pembangkit Bukit Asam Tanjung Enim perlu ditingkatkan lagi, jika Profesionalisme kerja karyawan semakin baik maka kinerja karyawan juga akan baik.

Dengan cara mengembangkan keahlian, mahir membangun hubungan dan memiliki nilai moral yang tinggi. Semakin tinggi profesionalisme karyawan, maka semakin tinggi pula kinerja karyawan tersebut.

\section{DAFTAR PUSTAKA}

Abdullah Ardi. 2017. Pengaruh Profesionalisme dan Komitmen Organisasi terhadap Kinerja Pegawai pada Kantor 
INSPEKTORAT

Provinsi

Sulawesi Selatan

Aisyah, Merisa Fajar, Wiji Utami, Sunardi, Sudarsih. 2015. Pengaruh Kualitas Sumber Daya Manusia , Profesionalisme Kerja, dan Komitmen Terhadap Kinerja Karyawan PDAM, kabupaten Jember. e--Journal Ekonomi Bisnis dan Akuntansi, 2017, Volume IV (1) :131-135. (file:///C:/Users/Hp/AppData/Loc al/Temp/4753-169-9023-1-1020170613.pdf)

Busro, Muhammad. 2018. Teori-teori Manajemen Sumber Daya Manusia. Cetakan ke-1. Jakarta: Prenadamedia Group.

Dessler, Gary. 2015. Manajemen Sumber Daya Manusia. Jakarta:Selemba Empat.

Gerhana, Wida, Rezti, Wasis.2019. Pengaruh Kualitas Sumber Daya Manusia dan Profesionalisme terhadap Kinerja Karyawan dengan Komitmen Organisasi sebagai Variabel Intervening (Studi Kasus pada Karyawan Dinas Pendidikan Hulu Sungai Selatan). urnal Riset Inspirasi Manajemen dan Kewirausahaan Volume 3 No. 1 Edisi Maret 2019 ISSN: 2549-3477 e-ISSN: 2623-1077 (https://ejurnal.stimibjim.ac.id)

Kasannudin, Mukhamad. 2011. Pengaruh Kualitas Sumber Daya Manusia (SDM) Pengelola Koperasi Terhadap Kinerja
Koperasi Pondok Pesantren di Kabupaten Demak. Skripsi. Semarang: Institute Agama Islam Negeri Walisongo Semarang.

http://library.walisongo.ac.id/digil ib/files/disk1/132/.

Mangkunegara. 2017. Manajemen Sumber Daya Perusahaan. Bandung: PT Remaja Rosdakarya

Sedarmayanti, 2010. Sumber Daya Manusia dan Produktivitas Kerja. Cetakan ke 2. Penerbit : Mandar Maju bandung.

Siagian P Sondang. 2010, Manajemen Sumber Daya Manusia. Rineka Cipta Jakarta.

Sugiyono, 2018. Metode penelitian Manajemen. Bandung: Alfabeta.

Sujarweni, 2015. Metode Penelitian Lengkap, Yogyakarta: Pustaka Baru Pers.

Suparno Eko Widodo. 2015. Manajemen Pengembangan SDM. Pustaka Pelajar.Jogjakarta.

Thamrin. Agung S,dkk 2017. Pengaruh profesionalisme kerja pegawai terhadap tingkat kepuasaan pelanggan pada kantor PT. Taspen cabang Manado. Jurnal Fakultas IImu Administrasi Fispol UNSRAT Manado

Wibowo, 2017. Manajemen kinerja Edisi ketiga. Jakarta: PT. Raja Grafindo 